\title{
Preliminary insights into the population characteristics and distribution of reef (Mobula alfredi) and oceanic ( $M$. birostris) manta rays in French Polynesia
}

\author{
Carpentier Alice S. 1, ${ }^{*}$, Berthe Cécile 1, 2, Ender Isabel ${ }^{3,4}$, Jaine Fabrice R. A. 5, 6, Mourier Johann 1, 2, 7 , \\ Stevens Guy ${ }^{3}$, De Rosemont Moeava ${ }^{8}$, Clua Eric ${ }^{1,2}$
}

\author{
${ }^{1}$ PSL Universite' Paris: EPHE-UPVD-CNRS, USR 3278 CRIOBE, BP 1013, 98729 Papetoai, Moorea, \\ French Polynesia \\ 2 Observatoire des Requins de Polyne'sie, Temae, 98728 Moorea, French Polynesia \\ 3 The Manta Trust, Catemwood House, Norwood Lane, Corscombe, Dorset DT2 0NT, UK \\ 4 James Cook University, 1 James Cook Drive, Townsville, QLD 4811, Australia \\ ${ }^{5}$ Sydney Institute of Marine Science, Mosman, NSW 2088, Australia \\ 6 Department of Biological Sciences, Macquarie University, North Ryde, NSW 2113, Australia \\ 7 UMR MARBEC (IRD, Ifremer, Univ. Montpellier, CNRS), Se`te, France \\ ${ }^{8}$ Association Manta Polynesia, Bora Bora, French Polynesia
}

* Corresponding author : Alice S. Carpentier, email address : alice s carpentier@hotmail.com

\begin{abstract}
:
In French Polynesia, both currently recognized manta ray species, Mobula alfredi and M. birostris, are observed. Despite being an important cultural asset and generating significant economic benefits through manta ray watching tourism, published data on the ecology and threats to these species in the region are scarce. Based on an 18-year dataset of sighting records collected by citizen scientists and during two scientific expeditions, this study provides the first insights into the population characteristics and regional distribution of the two manta ray species in French Polynesia. A total of 1347 manta ray photographs (1337 for M. alfredi and 10 for M. birostris) were examined for the period January 2001-December 2017, with photo-identification techniques leading to the successful identification of 317 individual $M$. alfredi and 10 individual M. birostris throughout the Society, Tuamotu and Marquesas Islands. We provide the first confirmation of sympatric distribution of both species in the Society Islands. Our results highlight strong and long-term site fidelity of $M$. alfredi individuals to certain aggregation sites (>9 years for 16 individuals) and reveal some degree of connectivity between populations, with 10 individuals recorded moving between islands located up to $50 \mathrm{~km}$ apart. Analysis of photographs of individuals bearing sub-lethal injuries $(n=68)$ suggests that $M$. alfredi are more likely to be injured at inhabited islands (Maupiti or Bora Bora; $75 \%$ of all injured individuals) than at uninhabited islands, with $75 \%$ of injuries related to boat propeller strikes and fishing gear entanglements. Our findings emphasize the need for further research to allow for a comprehensive evaluation of population structure, size and threats to manta rays in this region.
\end{abstract}

Keywords : Site fidelity, Citizen science, Sympatry, Spatial connectivity, Ecotourism management 


\section{Introduction}

Manta rays range among the largest elasmobranchs and are some of the most iconic marine species. Yet, many key aspects of their life history, ecology and distribution are still poorly understood (Couturier et al. 2012; Stewart et al. 2018). In 2009, Marshall et al. provided evidence of two distinct species of manta rays, now included in the genus Mobula (White et al. 2017): the oceanic manta ray Mobula birostris and the reef manta ray Mobula alfredi, distinguishable by their size, external coloration patterns, dentition and spine morphology. Mobula alfredi is widely distributed throughout the tropical and sub-tropical waters of the Pacific and Indian Oceans, although populations appear to be highly fragmented (Kashiwagi et al. 2011; Couturier et al. 2012). Mobula birostris is distributed throughout the tropics and up to latitudes $41^{\circ} \mathrm{N}$ and $\mathrm{S}$ (Kashiwagi et al. 2011). Reef manta ray $M$. alfredi is known to frequent the coastal reefs of continents and remote oceanic islands (Kashiwagi et al. 2011; Marshall et al. 2011b), also venturing offshore into the mesopelagic zone (Braun et al. 2014; Jaine et al. 2014). Oceanic manta ray M. birostris spend the majority of their time offshore and come into shallower regions along productive coastlines with regular upwellings (Marshall et al. 2011a; Stewart et al. 2016a). Both manta ray species demonstrate habitat fidelity and seasonal aggregation behaviours (Dewar et al. 2008; Jaine et al. 2012; Stewart et al. 2016; Couturier et al. 2018). They regularly visit specific sites on shallow reefs to clean (Homma et al. 1997; O'Shea et al. 2010; Jaine et al. 2012), engage in courtship behaviour and mating (Deakos 2011; Stevens et al. 2018a), or to feed (Jaine et al. 2012; Armstrong et al. 2016; Burgess et al. 2018). While some environmental variables (e.g. upwelling events, sea surface temperature, local prey density, tidal dynamics, wind speed, and moon cycles) have been identified as drivers of manta ray abundance and visitation patterns at a few locations globally (Dewar et al. 2008; O’Shea et al. 2010; Jaine et al. 2012; Rohner et al. 2013; Armstrong et al. 2016), it is important to establish these drivers more broadly to characterize critical habitats for these species (Stewart et al. 2018). 
Manta rays are particularly vulnerable to localized anthropogenic threats (Marshall et al. 2011; Dulvy et al. 2014), as they exhibit slow growth rates, late entry to maturity, and low fecundity (Lawson et al. 2017; Marshall and Bennett 2010; Stewart et al. 2018) that may prevent depleted populations from recovering. Targeted and bycatch fisheries and habitat degradation have resulted in manta ray population declines in recent decades (Ward-Paige et al. 2013; Rohner et al. 2013; Croll et al. 2017; Lawson et al. 2017). Poorly managed tourism development could also be impacting these species, especially at ecologically important aggregation sites (Rohner et al. 2013; Venables et al. 2016; Stevens and Froman 2018), although the impact tourism is having on these species behaviours and population dynamics is still unknown. Entanglement and boat strikes have also been identified as important sources of mortality to many threatened marine species (Mazzuca et al. 1998; Adimey et al. 2014; Asmutis-Silvia et al. 2017) and are being increasingly reported on mobulids (Couturier et al. 2012; Stewart et al. 2018; Stevens and Froman 2018). Both manta ray species are listed as 'Vulnerable' on the IUCN Red List of threatened species (Marshall et al. 2011a, 2011b), on Appendix II of the Convention on International Trade in Endangered Species (www.cites.org), and on Appendices I and II of the Convention on Migratory Species of Wild Animals (www.cms.int).

French Polynesia comprises 118 islands and atolls grouped into five archipelagos that extend over 2,000 kilometres in the South Pacific Ocean. In this region, manta rays are observed in all five archipelagos of French Polynesia (Randall et al. 1990; Laran et al. 2012), with both M. birostris and M. alfredi sympatrically occurring in the Marquesas Islands (Mourier 2012). Manta rays are particularly valuable for French Polynesia's ecotourism industry, as cleaning and feeding sites located around the islands of Bora Bora (Society Islands), Maupiti (Society Islands) and Tikehau (Tuamotu Islands) have become popular tourist attractions where visitors pay to swim or SCUBA dive with manta rays. In 2013, a study of the global economic impact of manta ray watching tourism revealed that manta ray tourism at three sites ("Anau" in Bora Bora, "The Pinnacle" in Maupiti, and "The Pearl Farm" in Tikehau) annually contributes US\$ 1.4 million to the local economy of French Polynesia (O’Malley et al. 2013). A later study that included two additional manta ray watching sites identified 
by tourism operators in Maupiti and in Bora Bora suggested that the value of manta ray tourism could now be as high as US\$ 3.6 million annually (Lagouy 2016). Occasional encounters with manta rays outside of dedicated manta dives, such as during dives in Tahiti (Society Islands), Rangiroa (Tuamotu Islands) or Fakarava (Tuamotu Islands), likely also contributes to the diving industry by greatly enhancing divers' experiences.

Whilst manta rays in French Polynesia are protected by the Code for the Environment among category "A" species (Articles A 121-3 to A 121-36, Code for the Environment of French Polynesia), they may be threatened by anthropogenic stressors related to the region's expanding marine megafauna tourism industry and coastal development (Stevens and Froman 2018). In Bora Bora, where the first manta ray watching tours were developed in the 1980s, there are strong beliefs from the local population that several declines in manta ray sightings noted at the site of Anau were directly caused by an increasing number of boats and tourists visiting the site or by several construction sites on the shoreline including two luxury hotels and a marina (M.D.R pers. obs., Lagouy 2016), despite the limited data available. Biological, environmental and temporal variables have been shown to influence manta ray visitation patterns at specific aggregation sites (Jaine et al. 2012; Rohner et al. 2013; Couturier et al. 2018; Stevens et al. 2018).

This paper aims to compile and analyse all existing photographic data gathered on manta rays in French Polynesia to provide preliminary insights into the ecology of these species, and to identify areas of critical habitat use to enable better conservation and management. Using photographicidentification principles (Marshall and Pierce 2012; Pierce et al. 2018), we identified individual manta rays photographed throughout French Polynesia to assess the population characteristics, distribution patterns and aggregation sites for both species in the region. The resulting data provided insights into site fidelity, habitat use and movements as well as population demographics and threats to manta rays in French Polynesia.

\section{Materials and methods}




\section{Individual identification and re-sighting data}

All manta ray sightings from the Society Islands and the Tuamotu Islands were opportunistically recorded by researchers, citizen scientists and collaborators of the "French Polynesia Manta Project" (FPMP). The FPMP was created in 2015 from a collaboration between the Manta Trust (www.mantatrust.org), a charitable organisation that coordinates global mobulid ray research and conservation, and the ORP ("Observatoire des Requins de Polynésie", www.requinsdepolynesie.com). The ORP was created in 2011 to allow members of the public to contribute observational data of sharks and rays. Participants are selected according to their experience and capacity to accurately identify shark and ray species (i.e. diving operators, regular local divers or researchers), to ensure the collection of robust data with reduced bias. The data collected through the ORP is then compiled and used to estimate population sizes, distribution and long-term trends of elasmobranchs in French Polynesia, in order to inform regional management and conservation.

Data were submitted either directly to the FPMP or via the ORP and Manta Trust citizen science platforms. Observers submitted their photographs along with the date and precise location of the sighting event (island and name of dive site or GPS coordinates). Where available, additional information on individual characteristics (size, sex, pregnancy status, presence of injuries or mating scars) and behavioural activity were provided by observers and subsequently validated by researchers. Sighting data from the Marquesas Islands were collected during two scientific expeditions: "Pakaihi I te Moana" led by the French Biodiversity Agency (2012) and RETROMAR led by the University of New Caledonia and the Center for Insular Research and Observatory of the Environment (CRIOBE, 2016-2017).

Manta ray species were identified as $M$. birostris or M. alfredi based on key morphological features and external colouration patterns documented in Marshall et al. (2009) and Stevens et al. 
(2018b). Photographs allowed for the identification of individual manta rays via matching of natural skin pigmentation and spot patterns on their ventral side, which are present from birth and remain unchanged over time (photographic-identification (photo-ID), Marshall et al. 2008; Marshall and Pierce 2012; Pierce et al. 2018). Photographs also allowed researchers to accurately identify the species, record physical abnormalities, determine the sex and maturity (when possible), and identify and track individuals overtime (Marshall and Pierce 2012). Only good-quality photographs with a clear image of the entire ventral side of manta rays were used for individual identification $(n=1,347)$. Images were compared and individuals identified manually. Identifications were validated by at least one other observer. Every photo-ID capture was recorded in a database generating an encounter history for each individual manta ray.

\section{Individual characteristics}

The sex of manta rays encountered was determined through the presence or absence of male reproductive organs (claspers). Observers also provided information on wounds and injuries. Photographs of all individuals reported with sub-lethal injuries were examined to investigate the origin of injuries based on their appearance. Photographs not showing the injuries clearly, showing minor marks or injuries from indeterminable origin were not included in the analysis. The origin of an injury was classified as 'natural' when related to predation attempts (i.e. crescent-shaped bite marks), 'anthropogenic' when it consisted of a clear cut caused by boat propellers or when the presence of a fishing line or hook on an individual was reported, and as 'unknown' when the cause of the injury could not be determined. 


\section{Site affinity and residency}

Maximum likelihood methods were used to model and estimate the amount of time individuals stayed at an aggregation site and simulate the expected number of individuals at each site following Whitehead (2001). In this method, the lagged identification rate (LIR), defined as the probability that an individual identified in a study area at time $t_{0}$ is re-sighted in the area after time $t$, can be obtained as a fitted function using observed data. This approach is appropriate for analysis of opportunistic data because it uses individual recapture locations as a proxy for sampling effort (Whitehead 2001). It has been previously used on a wide range of terrestrial and marine species population studies including on whale sharks, marine mammals (e.g. Ramírez-Macías et al. 2012; Whitehead 2001) and reef manta rays (Deakos et al. 2011; Germanov et al. 2019).

Eight models with varying degrees of assumed population closure were fitted to the data (Table 2). The parameters of each model were estimated using maximum likelihood estimation and binomial loss using the whole-study function of the SOCPROG 2.9 software (http://myweb.dal.ca/hwhitehe/social.htm/; Whitehead, 2009) in MATLAB 6.5 (MATLAB 2018b). The best-fit model was selected using the Akaike Information Criterion (AIC) or its quasi-variant (QAIC) depending on the presence of over-dispersion in the data (Burnham and Anderson 1998; Whitehead 2007). Differences of 0-2 between AIC or QAIC of the best-fit model and other models indicated strong support; 4-7 indicated some support; and differences greater than 10 indicated no support (Whitehead 2009). The most parsimonious model was then bootstrapped 1000 times to calculate standard error and estimate parameter precision to minimize the difference between observed and expected recaptures (Whitehead 2001). Plots of LIR against time were then produced for each site as these plots provided indications of the temporal use of the area by individuals. A declining function shows how rapidly individuals are leaving (dispersing), while a leveling-off over large time lags indicates that animals are either returning to the study area, or that some are permanent residents of the study area (Whitehead 2001). 


\section{RESULTS}

We examined a dataset consisting of 1,347 manta ray photographic sighting records $(1,337$ for $M$. alfredi and 10 for $M$. birostris) collected in 3 archipelagos of French Polynesia (i.e. Society Islands, Tuamotu Islands and Marquesas Islands) between 2001-2018. From these, a total of 317 individual M. alfredi and 10 M. birostris were successfully identified via photo-ID (Table 1), consisting of 143 males and 157 females for $M$. alfredi and 1 male and 6 females for M. birostris. Sex could not be determined for 10 individual M. alfredi and 3 individual M. birostris in the dataset.

\section{Photographic data collection}

From all sighting records examined as part of this dataset, 1,102 originated from 5 islands throughout the Society Islands (i.e. Tahiti, Moorea, Bora Bora, Maupiti and Tetiaroa), 169 sightings were recorded at 4 islands of the Tuamotu Islands (i.e. Tikehau, Rangiroa, Fakarava, Hao), and 66 sightings were recorded from 6 islands in the Marquesas Islands (i.e. Eiao, Nuku Hiva, Ua Huka, Hatutaa, Hiva Oa, Tahuata) (Fig. 1). The majority of sighting records were collected at three popular M. alfredi aggregation sites by local diving operators: the sites of Anau in Bora Bora (16²9' S; $151^{\circ} 42^{\prime}$ W) and Maupiti $\left(16^{\circ} 25^{\prime} \mathrm{S} ; 152^{\circ} 14^{\prime} \mathrm{W}\right)$ in the Society islands (271 and 816 sighting records respectively), and the site of Tikehau in the Tuamotu Islands $\left(15^{\circ} 06^{\prime} \mathrm{S} ; 148^{\circ} 12^{\prime} \mathrm{W}\right)$ with 140 photographic sighting records. Combined sighting data from those three sites represented $95.8 \%$ of all $M$. alfredi sighting data presented in this study for the greater French Polynesia region. The data collection effort varied across years at each of these three sites (Fig. 2). In Bora Bora, photographs were submitted regularly between August 2002 and January 2006, with little contribution until May 2016. In Maupiti, the sighting data collection started in 2014, and was very consistent until November 2015. 
Additional sighting information is derived from opportunistic observations made by coauthors and members of the ORP off the coasts of Tahiti, Moorea and Tetiaroa in the Society Islands, and off Rangiroa and Fakarava in the Tuamotu Islands.

Sightings of individual M. birostris were recorded around Tahiti and Moorea in the Society Islands (n=3) and from Nuku Hiva and Ua Pou in the Marquesas Islands (n=7) (Fig. 1).

\section{Distribution and population characteristics}

\section{M. alfredi}

In the Society Islands, a total of 107 individual $M$. alfredi were identified at the island of Bora Bora (53 females, 52 males and 2 of unknown sex, 2001-2018) and 51 at the site of Maupiti (30 females and 21 males, 2014-2016). Additionally, one female individual was sighted in Tahiti and Moorea (2015-2017) and one female individual was recorded in Tahiti. The individual identified at Tetiaroa was of undetermined sex. Proportions of females and males were almost equal at aggregation sites off Bora Bora and Maupiti, with female to male ratios of 1:1.1 $\left(\chi^{2}=0.009, \mathrm{df}=1, \mathrm{p}=0.92\right)$ and 1:1.4 $(\chi 2=1.59, \mathrm{df}=1, \mathrm{p}=0.21)$ respectively $($ Table 1$)$.

In the Tuamotu Islands, 77 individual $M$. alfredi, including 35 females and 34 males, were identified at the Tikehau site, 20 at Hao (10 females, 8 males and 2 of unknown sex), three females and one male at Rangiroa, and 1 individual of unknown sex in Fakarava. There was no significant difference between the proportion of females to males at Tikehau $(\chi 2=0.014, d f=1, p=0.90)$, and there were slightly more males than females at Hao site $(\chi 2=0.22, d f=1, \mathrm{p}=0.63)$, with a 1:1.3 female to male ratio.

In the Marquesas Islands, 63 individual M. alfredi were identified in total, with 32 individuals at the site of Eiao (20 females and 8 males, 4 of unknown sex), 22 individuals in Nuku Hiva (14 females and 7 males, one of unknown sex), one individual of unknown sex at the site of Ua Huka, 
one female individual at Hatutaa, three female and four male individuals at Hiva Oa, and one female and one male individuals at Tahuata. Although sample size was low, the population of Eiao was biased towards females $(\chi 2=5.14, d f=1, \mathrm{p}=0.02)$, with a female to male ratio of 2.5:1 (Table 1$)$.

\section{M. birostris}

A total of 10 individual M. birostris were identified throughout French Polynesia as part of this study.

Of the three individuals identified in the Society islands, two were observed cruising off Tahiti and were of unknown sex, and the third individual was a female observed cruising off Moorea.

Seven M. birostris were identified in the Marquesas Islands; three individuals in Ua Pou (two females and one of unknown sex), and four individuals at Nuku Hiva (three females and one male). All individuals were observed cruising past these sites.

To date none of the identified M. birostris individuals have been re-sighted in the greater French Polynesia region.

\section{Site affinity and residency of $M$. alfredi}

In the Society islands, reef manta ray $M$. alfredi displayed high site fidelity around the islands of Bora Bora and Maupiti, with $35.51 \%(n=107)$ and $90.20 \%(n=51)$ of the locally identified population being re-sighted at each site respectively (Table 1). The mean number of re-sightings for an individual at Bora Bora was $7.87 \pm 6.08(n=46)$ and $18.87 \pm 14.55(n=38)$ for the site of Maupiti. Two individuals were re-sighted up to 51 and 52 times at Maupiti between March 2014 and November 2015. Overall, long re-sighting periods (i.e. time interval between first and last sighting event) were recorded, with an average of 1,999 days (i.e. $~ 5.5$ years) at Bora Bora $(n=38)$, and with 16 individuals re-sighted for periods of over 9 years. The longest re-sighting period was 5,565 days ( 15.25 years) for a mature female individual at the site of Bora Bora. Manta rays from the Tuamotu islands also showed some 
site affinity, as $51 \%$ and $20 \%$ of all manta rays identified respectively at the sites of Tikehau and Hao were re-sighted at least once. The maximum number of re-sightings for an identified manta ray was seven at the Tikehau site, and the mean number of re-sightings for this aggregation site was $2.70 \pm$ 1.23 ( $n=37)$. In the Marquesas islands, two individuals were re-sighted at the site of Eiao (12.5\% of all manta rays identified at this site), with intervals between sightings of 63 and 64 days, respectively.

Based on the time lags between manta ray re-sightings, the lagged identification rate (LIR) was calculated and plotted for Bora Bora, Maupiti and Tikehau aggregation sites (Fig. 4). Only the periods with the most data were used in the analyses: 2002-2004 data for Bora Bora, 2011-2013 data for Tikehau and 2015 data for Maupiti (Fig. 2). Within each site, the LIR dropped at time lags from 1 to approximately 150 days, suggesting individuals stayed in the area seasonally and then left. The lagged identification rate remained stable until the end of each study period, suggesting return to the same area in successive months. Models A to H (Table 2) were fitted to the LIR for each site separately, and the model F, that accounts for emigration and immigration, was selected for the three sites according to the QAIC for Bora Bora's data (accounting for over-dispersion in the data) and the AIC for Maupiti and Tikehau's data (no sign of over-dispersion in the data). The model indicates that there was an average daily abundance of 16 manta rays $(16.39 \pm$ s.e. $=6.62,95 \%$ c.i. $10.57-35.04)$, 35 manta rays $(35.37 \pm$ s.e. $13.56,95 \%$ c.i. $9.96-63.77)$ and 24 manta rays $(23.62 \pm$ s.e. $=2.53,95 \%$ c.i. 18.98 - 28.47) at the sites of Bora Bora, Tikehau and Maupiti respectively. An individual remained in the aggregation site an average of $65.83( \pm$ s.e. $=290.36)$ days, $70.80( \pm$ s.e. $=129.11)$ days and $129.89( \pm$ s.e. $=94.31)$ days at the sites of Bora Bora, Tikehau and Maupiti respectively. Individuals were estimated to spend an average of $76.54\left( \pm\right.$ s.e. $\left.=3.19 \mathrm{e}^{11}\right)$ days, $116.62( \pm$ s.e. $=$ $\left.8.15 \mathrm{e}^{13}\right)$ days and $58.75\left( \pm\right.$ s.e. $\left.=6.01 \mathrm{e}^{10}\right)$ days outside the sites of Bora Bora, Tikehau and Maupiti respectively. 


\section{Regional movements of $M$. alfredi}

Nine individual $M$. alfredi that were first identified around Bora Bora and re-sighted regularly between 2002-2006 (Fig. 2) were subsequently re-sighted at the Maupiti aggregation site when the monitoring started in 2014. From those nine individuals, seven were re-sighted several times at both sites, with the two islands located $\sim 50 \mathrm{~km}$ apart and separated by waters over 3,000 $\mathrm{m}$ depth (Clouard and Bonneville 2004). Four of these individuals were then re-sighted again in Bora Bora in 2016, whereas the sampling effort in Maupiti stopped around that time (Fig. 2).

One female $M$. alfredi was observed 10 times at two popular SCUBA diving sites off Tahiti between April 2015-June 2016, then re-sighted in Moorea in May 2016, in Tahiti again in November 2016, and last seen in Moorea in April 2017. Those sites are located on neighbour islands $~ 35 \mathrm{~km}$ apart and separated by waters over 2,000 $\mathrm{m}$ depth.

In the Marquesas Islands, two individual $M$. alfredi were re-sighted at two sites around the same island (Eiao) located $\sim 7.5 \mathrm{~km}$ apart.

\section{Injuries}

From all manta rays recorded bearing wounds or injuries in French Polynesia $(n=68)$, $75 \%$ were observed at the sites of Bora Bora and Maupiti (Society Islands), 13\% in the Tuamotu Islands and $6 \%$ in the Marquesas Islands. Most of the injuries were of anthropogenic origin, with $75 \%(n=39)$ of all injuries observed at Bora Bora and Maupiti appearing to be related to boat propellers (Fig. 3A) or fishing gear (Fig. 3B). One injury was attributed to a predator bite in the Society islands (Fig. 3C).

From all identified manta rays in the Tuamotu Islands, 11 individuals had visible injuries (8.11\%), but the photographs submitted did not allow for the determination of whether those injuries were of natural or anthropogenic origin. 
Five out of the 53 manta rays identified in the Marquesas Islands exhibited injuries $(9.43 \%$ of all identified manta rays). One of them was of anthropogenic origin, one was attributed to a predator attack (Fig. 3C), and three could not be assigned an origin from the submitted photographs.

\section{Discussion}

Based on an 18-year photo-ID dataset contributed by citizen scientists and members of the research team, this study provides the first insights into the distribution patterns and population characteristics of the two currently recognised manta ray species in French Polynesia. It reports on strong and longterm fidelity of reef manta rays $M$. alfredi to specific sites in the region, as well as evidence of interisland connectivity between some populations. Finally, reports of injuries and their origin suggest the manta rays are more likely to get injured in inhabited islands than in sparsely populated islands.

\section{Sympatry of M. alfredi and M. birostris in French Polynesia}

While the sympatric distribution of both manta species had previously only been reported for the Marquesas Islands (Mourier 2012), we provide here the first confirmed evidence of sympatry occurring in the Society Islands. However, in contrast with M. alfredi that have been shown to have a long-term and relatively high fidelity to some specific aggregation sites in the Society Islands, only three M. birostris individuals were opportunistically reported in this archipelago during the study. As these individuals were observed separately cruising along the outer reef or in the open ocean, and no M. birostris aggregation sites have been identified in the Society Islands, we suggest that $M$. birostris are transients to this archipelago. The fact that $M$. birostris have not been observed at $M$. alfredi aggregation sites in the Society Islands also indicates that the two species are likely to have different habitat use requirements. Further investigation of environmental influences on manta ray presence in 
French Polynesia is required to understand why M. birostris are uncommonly sighted in other archipelagos of French Polynesia.

\section{Population distribution}

Considering that French Polynesia is made of 118 islands extending over an area of more than $4,167,000 \mathrm{~km}^{2}$ and most islands being uninhabited or difficult to access, the results on population distribution provided in this study likely consist of only a fraction of the actual distribution of manta rays in the region. During an aerial survey of marine mammals and other pelagic megafauna (REMMOA campaign led by the French Biodiversity Agency) undertaken in 2011, which covered all French Polynesia's territory, manta rays were observed in all five archipelagos, including the Austral and Gambier Islands (Laran et al. 2013). The present study only analysed sighting data for which photographs were provided, and thus did not include manta ray data from sites that had been previously reported by visual observations, such as "the Pass" in Bora Bora, known as a cleaning station (M.D.R. pers. obs.) and an additional site at Maupiti (Lagouy 2016). Finally, the data presented in this study came mostly from collaborators already involved in citizen science programs, and it is likely that many additional manta ray observers were not aware of the existence of a photoID program for manta rays in French Polynesia. Soliciting the public through the organization of informative interventions and interviewing local diving clubs and fishermen on islands where manta rays are encountered will help to refine current knowledge of the occurrence and habitat use of manta rays in the region.

\section{Site affinity and residency}

Frequent and long-term re-sightings periods of individuals $M$. alfredi are reported in this study at the sites of Bora Bora, Maupiti and Tikehau. Maupiti's proportion of re-sighted individuals (90\%, $n=51)$ 
is the highest documented to date in studied manta ray populations worldwide, followed by a resighting rate of $82 \%$ in the Nusa Penida site in Indonesia ( $n=624,2012-2018$, Germanov et al. 2019), $73 \%$ in the West coast of Maui, Hawaii $(n=290,2005-2009$, Deakos et al. 2011) and 63\% at a site in Lady Eliot Island, Australia ( $n=449,2003-2007$, Couturier et al. 2014). Thanks to long-term data available for the site of Bora Bora, long re-sighting periods were recorded at this site, with an average period of 1,999 days between first and last sightings of individuals $(n=38)$ and 16 individuals that were re-sighted over periods of $>9$ years. The longest re-sighting period of 5,565 days ( 15.3 years) for a female individual reported at this site is also among the longest reported in the literature, as 5,629 days had been reported for an individual at the site of Kona, Hawai'i ( $\sim 15.4$ years, Clark 2010) and 13.8 years for an individual at the site of the Nusa Penida, Indonesia (Germanov et al. 2019). While the long re-sighting periods reported ascertain the long-term, potentially life-long use of some sites by $M$. alfredi, they do not extend the current knowledge of longevity for this species, as photographic records show they can live for at least 30 years (Clark 2010; Couturier et al. 2014; Homma et al. 1997; Kashiwagi et al. 2011; Stevens 2016). They are estimated to reach about 40 years, although maximum longevity remains unknown (Couturier et al. 2012).

Results on long-term site affinity are further highlighted by lagged identification rate analysis, which indicated that some individuals are staying in the aggregation sites of Bora Bora, Maupiti and Tikehau seasonally, and then leave the site, following emigration and immigration patterns. It confirms the existence of seasonality in manta ray sightings in these aggregation sites, with a peak season reported to be between the end of April and the beginning of September for Bora Bora (M.D.R, pers. obs.). It was not possible to evaluate these trends in the current study as the sampling effort was not consistent in time and limited on photographic sighting data only, which did not reflect the reported seasonal patterns at each site. Results of LIR analysis also suggested that either some individuals did not leave the sites during the study periods or that they returned in successive months (Whitehead 2001), which indicates that those individuals may be resident to those specific sites. 
Residency of individual manta rays has also been documented in other sites of the world, such as in Hawai'i (Deakos 2010), Mozambique (Marshall 2008) and in the Red Sea (Braun et al. 2015).

The mean probability of re-identifying an individual manta ray within the same aggregation site from the time of first identification was about 150 days for all three studied sites (Bora Bora, Maupiti and Tikehau), which is very similar to LIR results obtained for the M. alfredi population of the west coast of Maui, Hawaii (Deakos et al. 2011). However, these time lags are much shorter than the time lags of about 6 years estimated through similar maximum likelihood approaches for $M$. alfredi within two study areas in Indonesia (Germanov et al. 2019).

Precise investigation of individual behaviors and environmental factors' variation that may affect visitation patterns (e.g. Jaine et al. 2012; Armstrong et al. 2016) should be undertaken at each site in order to better understand the site affinities and function of each site for the population.

\section{Regional movements and population connectivity}

In the Society Islands, nine individual $M$. alfredi were recorded at both the Bora Bora and Maupiti aggregation sites, located $\sim 50 \mathrm{~km}$ apart and separated by deep oceanic waters (> 3,000 $\mathrm{m}$ depth). The sampling effort started in Maupiti in 2014, which corresponds to when the nine individual manta rays initially identified in Bora Bora were sighted in Maupiti, with four individuals then re-sighted again in Bora Bora as regular monitoring resumed after a period of $\sim 8$ years with very low sampling effort. As there has been almost no monitoring at both sites at the same time (except for a few months at the beginning of 2016), the available data did not allow us to determine whether these individuals undertook these movements routinely, seasonally, every year or once every few years. Therefore, long-term, consistent monitoring effort at both sites is required to evaluate the frequency of these movements. The species has been reported to routinely undertake regional movements between aggregation sites in various localities across its range. For instance, a similar photo-ID program along the east coast of Australia detected long-term seasonal movements of individual $M$. alfredi between 
sites located up to $750 \mathrm{~km}$ apart (Couturier et al. 2011, 2014). Additional satellite tracking of $M$. alfredi in the same region (Great Barrier Reef, Australia) revealed that individuals moved extensively and undertook offshore excursions to travel between sites and forage productive oceanographic features (Jaine et al. 2014). However, few studies to date have documented connectivity between $M$. alfredi populations observed at separate oceanic islands (e.g. Germanov and Marshall 2014) and it has been suggested that deep water channels may act as barriers to inter-island movements (Deakos et al. 2011). Our results show that connectivity between nearby islands of a same archipelago occurs in French Polynesia, however the current dataset does not allow for the evaluation of connectivity with other sites on a larger geographic scale, notably between archipelagos. These results also question whether manta ray populations using different aggregation sites, islands or archipelagos of French Polynesia consist of different genetic stocks or can be attributed to a single genetic profile. The application of region-wide satellite tracking and genetic analyses will help ascertain population structure and gene flow (e.g. Stewart et al. 2016). The observed inter-island movements of M. alfredi in the region (Moorea-Tahiti, Bora Bora-Maupiti) could be attributed to the need to acquire sufficient resources or to reproduce, as is the case for blacktip reef sharks in the region (Mourier and Planes 2013).

\section{Distinctive injuries observed on manta rays}

Results from this study confirm that manta rays are more likely to get injured around inhabited islands with high marine traffic (e.g. Maupiti or Bora Bora) than at remote uninhabited islands (e.g. Marquesas Islands). Most of the sub-lethal injuries observed in the dataset were of anthropogenic origin, with $85 \%$ and $53 \%$ of all injuries observed at the sites of Bora Bora and Maupiti assigned to propellers and fishing gear. Several individuals were observed with either line or hook still attached to their bodies, highlighting that entanglement in fishing lines is a significant threat to manta rays in the Society Islands. Serious injuries to organisms can delay the age at sexual maturity or prevent 
females from mating while recovering from their wounds (Harris 1989), and catch-induced stress has been suggested as a primary cause of early abortion in elasmobranchs (Adams et al. 2018). Additionally, injuries may also influence the time and frequency of manta rays visiting cleaning stations, as it has been suggested that injured individuals may stay longer at cleaning stations to promote wound healing (Heithaus 2001; Marshall et al. 2011). Therefore, injuries to manta rays can negatively impact an individual's health, their ability to reproduce or their reproductive behaviour, which can directly influence population growth (Le Boeuf et al. 1982; Heithaus 2001) and distribution, as shown in other parts of the world (e.g. Deakos et al. 2011). Assessment of the habitat use of manta rays using acoustic or satellite tracking techniques will assist in determining areas of overlap with the local fishery and refining management strategies. Regulating fishing activity and boat traffic in areas critical to manta rays will help reduce the frequency of entanglements, injuries or human-induced fatalities.

Manta rays are important cultural and socio-economic assets in French Polynesia. Yet, results from our study indicate that they may be threatened by a suite of anthropogenic stressors related to the region's expanding marine megafauna tourism industry and coastal development. The citizen science approach used in this study has allowed the collation of a valuable dataset of manta ray sightings over nearly two decades. The resulting dataset yielded preliminary information on population structure, distribution and connectivity of manta rays in French Polynesia and shows that a small number of reliable contributors (i.e. 20 photographers) can help provide essential scientific information at no financial cost for scientists. However, some key aspects of the ecology of manta rays in the region could not be elucidated due to the spatially and temporally limited dataset. Further and consistent monitoring effort across the various archipelagos is required to 1) describe precisely the distribution and population structure (i.e. sex-ratios, population sizes at each site, individual sizes, reproduction ecology) of manta rays in the region; 2) investigate drivers of occurrences and identify common influences across sites; 3 ) evaluate the genetic and spatial connectivity between populations; 
and 4) identify critical habitats to inform future manta ray conservation and management. If addressed, these combined knowledge gaps will allow implementing effective conservation management plans for manta ray populations in French Polynesia, and will contribute to current understanding of these globally vulnerable species.

\section{Acknowledgements}

This work was part of the French Polynesia Manta Ray Project, initiated in 2015 thanks to a collaboration between the Manta Trust and the ORP. We are very grateful to all the divers, snorkelers, and members of the ORP that contributed photographs, especially N. Buray, director of the ORP, Y. Verdez and N. Massoud (Maupiti Diving) for the photographs collected in Maupiti, R. Carter and G. Banton for those from Bora Bora collected in 2016 and their work in analyzing some of the historical data presented in this study, and V. Truchet for the photographs collected in Tikehau, as well as : T. Athenol, M. Bègue, H. Blitz, B. Le Bouil, P. Carzon, B. Cauchard, F. Chasboeuf, M. Clavreul, Al. Dargie, A. Deliere, J. Dorio, O. Duguet, F. Farabaugh (Global footprint), P. Fey, S. Gadea, G. Lagarrigue, C. Hoogstoel, L. Lechat, T. Maire, D. Melzani, C. Mulard, H. Mura, M. Petit (Moorea Ocean Adventures), P. Schneider, C. Serin, M. Tavernier, E. Preyzner. We thank E. Germanov for her help in the LIR analysis. We also thank Topdive and Le Méridien, Bora Bora for their logistical and financial support in the Bora Bora data collection. We thank L. Hoarau (RRR) and T. Leclerc for their help on the GIS, and P. Firouzian and CEDTM/Kelonia for their logistical support during the writing of this manuscript. Finally, we thank two anonymous reviewers for their constructive comments on this manuscript.

\section{Conflict of interest statement}

On behalf of all authors, the corresponding author states that there is no conflict of interest. 


\section{References}

Adams KR, Fetterplace LC, Davis AR, Taylor MD, Knott NA (2018) Sharks, rays and abortion: the prevalence of capture-induced parturition in elasmobranchs. Biol Conserv 217:11-27

Adimey NM, Hudak CA, Powell JR, Bassos-Hull K, Foley A, Farmer NA, White L, Minch K (2014) Fishery gear interactions from stranded bottlenose dolphins, Florida manatees and sea turtles in Florida, USA. Mar Pollut Bull 81:103-115

Anderson RC, Adam MS, Goes JI (2011) From monsoons to mantas: seasonal distribution of Manta alfredi in the Maldives. Fisheries Oceanogr 20:104-113

Armstrong AO, Armstrong AJ, Jaine FR, Couturier LI, Fiora K, Uribe-Palomino J, Richardson AJ (2016) Prey density threshold and tidal influence on reef manta ray foraging at an aggregation site on the Great Barrier Reef. PLoS One 11(5):e0153393

Asmutis-Silvia R, Barco S, Cole T, Henry A and others (2017) Rebuttal to published article 'A review of ghost gear entanglement amongst marine mammals, reptiles and elasmobranchs' by M. Stelfox, J. Hudgins, and M. Sweet. Mar Pollut Bull 117:554-555

Braun CD, Skomal GB, Thorrold SR, Berumen ML (2014) Diving behavior of the reef manta ray links coral reefs with adjacent deep pelagic habitats. PLoS One, 9(2):e88170

Braun CD, Skomal GB, Thorrold SR, Berumen ML (2015) Movements of the reef manta ray (Manta alfredi) in the Red Sea using satellite and acoustic telemetry. Mar Biol 162(12):2351-2362

Burgess KB, Guerrero M, Richardson AJ, Bennett MB, Marshall AD (2017) Use of epidermal mucus in elasmobranch stable isotope studies: a pilot study using the giant manta ray (Manta birostris). Mar Fresh Res 69:336-342

Burnham KP, Anderson DR (1998) Model Selection and Inference: A Practical InformationTheoretic Approach. Springer-Verlag, New York

Clark TB (2010) Abundance, home range, and movement patterns of manta rays (Manta alfredi, M. birostris) in Hawai'i. Ph.D. thesis, University of Hawaii at Manoa

Clouard V, Bonneville A (2004) Submarine landslides in French Polynesia. In: Hekinian R (ed) Oceanic Hotspots. Springer, Berlin, Heidelberg, pp 209-238

Coles RJ (1916) Natural history notes on the devil-fish, Manta birostris (Walbaum) and Mobula olfersi (Müller). Bulletin American Museum of Natural History 35:649-657

Couturier LIE, Jaine FRA, Townsend KA, Weeks SJ, Richardson AJ, Bennett MB (2011) Distribution, site affinity and regional movements of the manta ray, Manta alfredi (Krefft, 1868), along the east coast of Australia. Mar Freshw Res 62:628-637

Couturier LIE, Marshall AD, Jaine FR, Kashiwagi T, Pierce SJ, Townsend KA, Weeks SJ, Bennett MB, Richardson AJ (2012) Biology, ecology and conservation of the Mobulidae. J Fish Biol 80:1075-1119 
Couturier LIE, Rohner CA, Richardson AJ, Marshall AD, Jaine FRA (2013) Stable isotope and signature fatty acid analyses suggest reef manta rays feed on demersal zooplankton. PLoS One 8(10):e77152

Couturier LI, Dudgeon CL, Pollock KH, Jaine FRA, Bennett MB, Townsend KA, Weeks SJ, Richardson AJ (2014). Population dynamics of the reef manta ray Manta alfredi in eastern Australia. Coral Reefs 33(2):329-342

Couturier LIE, Newman P, Jaine FRA, Bennett MB, Venables WN, Cagua EF, Townsend KA, Weeks SJ, Richardson AJ (2018) Variation in occupancy and habitat use of Mobula alfredi at a major aggregation site. Mar Ecol Prog Series 599:125-145

Croll DA, Dewar H, Dulvy NK, Fernando D, Francis MP, Galván-Magaña F, Hall M, Heinrichs S, Marshall A, Mccauley D, Newton KM, Notarbartolo di Scaria G, O'Malley M, O'Sullivan J, Poortvliet M, Roman M, Stevens G, Tershy BR, White WT (2016). Vulnerabilities and fisheries impacts: the uncertain future of manta and devil rays. Aqua Conserv Mar Freshw Ecosyst 26:562-575

Deakos MH (2010) Ecology and social behavior of a resident manta ray (Manta alfredi) population off Maui, Hawai'i. Ph.D. thesis, University of Hawaii at Manoa

Deakos MH, Baker JD, Bejder L (2011) Characteristics of a manta ray Manta alfredi population off Maui, Hawaii, and implications for management. Mar Ecol Prog Ser 429:245-60

Deakos MH (2012) The reproductive ecology of resident manta rays (Manta alfredi) off Maui, Hawaii, with an emphasis on body size. Environ Biol Fish 94:443-456

Dewar H, Mous P, Domeier M, Muljadi A, Pet J, Whitty J (2008) Movements and site fidelity of the giant manta ray (Manta birostris), in the komodo Marine Park, Indonesia. Mar Biol 155(2):121-133

Duffy CAJ, Abbott D (2003) Sightings of mobulid rays from northern New Zealand, with confirmation of the occurrence of Manta birostris in New Zealand waters. Mar Freshw Res 37:715721

Dulvy NK, Pardo SA, Simpfendorfer CA, Carlson, JK (2014). Diagnosing the dangerous demography of manta rays using life history theory. PeerJ 2, e400

Germanov ES, Marshall AD (2014). Running the gauntlet: regional movement patterns of Manta alfredi through a complex of parks and fisheries. PloS one 9(10):e110071

Germanov ES, Bejder L, Chabanne DBH, Dharmadi D, Hendrawan, IG, Marshall AD, Pierce SJ, van Keulen M, Loneragan NR (2019) Contrasting habitat use and population dynamics of reef manta rays within the Nusa Penida marine protected area, Indonesia. Front Mar Sci 215:1-14

Harris RN (1989) Non-lethal injury to organisms as a mechanism of population regulation. Am Nat 134:835-847

Heithaus MR (2001) Shark attacks on bottlenose dolphins (Tursiops aduncus) in Shark Bay, Western Australia: attack rate, bite scar frequencies, and attack seasonality. Mar Mammal Sci 17:526-539 
Homma K, Maruyama T, Itoh T, Ishihara H, Uchida S (1997) Biology of the manta ray, Manta birostris, Walbaum, in the Indo-Pacific. In: Séret B, Sire JY (eds) Proceedings of the 5th Indo-Pacific Fish Conference, Nouméa. Soc Fr Ichthyol, Paris, pp 209-216

Jaine FR, Couturier LI, Weeks SJ, Townsend KA, Bennett MB, Fiora K, Richardson AJ (2012) When giants turn up: sighting trends, environmental influences and habitat use of the manta ray Manta alfredi at a coral reef. PloS one 7(10):e46170

Jaine FRA, Rohner CA, Weeks SJ, Couturier LIE, Bennett MB, Townsend KA, Richardson AJ (2014) Movements and habitat use of reef manta rays off eastern Australia: offshore excursions, deep diving and eddy affinity revealed by satellite telemetry. Mar Ecol Prog Ser 510:73-86

Kashiwagi T, Marshall AD, Bennett MB, Ovenden JR (2011) Habitat segregation and mosaic sympatry of the two species of manta ray in the Indian and pacific Oceans: Manta alfredi and $M$. birostris. Mar Biodivers Rec 4:E53

Lagouy E (2016) L'écotourisme animalier en Polynésie Française. In: Rapport final pour l'Agence des Aires Marines Protégées (Final report for the French Biodiversity Agency, Ministry of the Environment)

Laran S, Van Canneyt O, Doremus G, Massart W, Ridoux V, Watremez P (2012) Distribution et abondance de la mégafaune marine en Polynésie française. REMMOA- Polynésie. In: Rapport final pour l'Agence des Aires Marines Protégées (Final report for the French Biodiversity Agency, Ministry of the Environment)

Lawson JM, Walls RHL, Fordham SV, Heupel MR, Stevens G, Fernando D, Budziak A, Simpfendorfer CA, Davidson LNK, O’Malley MP, Ender I, Francis MP, Notarbartolo di Sciara G, Dulvy NK (2017). Sympathy for the devil: a conservation strategy for devil and manta rays. PeerJ 5, e3027

Le Boeuf BJ, Riedman M, Keyes RS (1982) Shark predation on pinnipeds in California coastal waters. United States National Marine Fisheries Fishery Bulletin 80:891-895

Marshall AD (2008) Biology and population ecology of Manta birostris in southern Mozambique, Ph.D. thesis, University of Queensland

Marshall AD, Bennett MB (2010). The frequency and effect of shark-inflicted bite injuries to the reef manta ray Manta alfredi. Afr J Mar Sci 32(3):573-580

Marshall AD, Compagno LJV, Bennett MB (2009) Redescription of genus Manta with resurrection of Manta alfredi (Krefft, 1868) (Chondrichthyes, Myliobatoidei, Mobulidae). Zootaxa 2301:1-28

Marshall A, Bennett MB, Kodja G, Hinojosa-Alvarez S, Galvan-Magana F, Harding M, Stevens, G, Kashiwagi T (2011a) Manta birostris. The IUCN Red List of Threatened Species Version 2011.2. http://www.iucnredlist.org

Marshall A, Kashiwagi T, Bennett MB, Deakos M, Stevens G, McGregor F, Clark T, Ishihara H, Sato K (2011b) Manta alfredi. The IUCN Red List of Threatened Species Version 2011.2. http://www.iucnredlist.org 
Marshall AD, Dudgeon CL, Bennett MB (2011) Size and structure of a photographically identified population of manta rays Manta alfredi in southern Mozambique. Mar Biol 158:1111-1124

Marshall, AD, Pierce SJ (2012) The use and abuse of photographic identification in sharks and rays. J Fish Biol 80:1361-1379

Mazzuca L, Atkinson S, Nitta E (1998) Deaths and entanglements of humpback whales, Megaptera novaeangliae, in the main Hawaiian Islands, 1972-1996

Mourier J (2012) Manta rays in the Marquesas Islands: first records of Manta birostris in French Polynesia and most easterly location of Manta alfredi in the Pacific Ocean, with notes on their distribution. J Fish Biol 81:2053-2058

Mourier J, Vercelloni J, Planes S (2012) Evidence of social communities in a spatially structured network of a free-ranging shark species. Anim Behav 83(2):389-401

Mourier J, Planes S (2013) Direct genetic evidence for reproductive philopatry and associated fine-scale migrations in female blacktip reef sharks (Carcharhinus melanopterus) in French Polynesia. Mol Ecol 22:201-214

O’Malley MP, Lee-Brooks K, Medd HB (2013) The global economic impact of manta ray watching tourism. PLoS One 8

O'Shea OR, Kingsford MJ, Seymour J (2010) Tide-related periodicity of manta rays and sharks to cleaning stations on a coral reef. Mar Freshw Res 61:65-73

Pierce SJ, Holmberg J, Kock AA, Marshall AD (2018) Chapter 12: Photographic identification of sharks. In: Carrier, Heithaus, Simpfendorfer (eds) Shark research: emerging technologies and applications for the field and laboratory. CRC Press, 392p.

Ramírez-Macías D, Vázquez-Haikin A, Vázquez-Juárez R (2012) Whale shark Rhincodon typus populations along the west coast of the Gulf of California and implications for management. End Spec Res 18:115-128

Randall JE, Smith CL, Feinberg MN (1990) Report on fish collections from Rapa, French Polynesia. Am. Mus. Nov, 2966: 44p.

Rohner CA, Pierce SJ, Marshall AD, Weeks SJ, Bennett MB, Richardson AJ (2013) Trends in sightings and environmental influences on a coastal aggregation of manta rays and whale sharks. Mar Ecol Prog Ser 482:153-168

Stevens GMW (2016) Conservation and population ecology of Manta rays in the Maldives. Ph.D. thesis, University of York

Stevens GM, Hawkins JP, Roberts CM (2018a) Courtship and mating behaviour of manta rays Mobula alfredi and M. birostris in the Maldives. J Fish Biol 93(2):344-359

Stevens G, Fernando D, Dando M, Notabartolo-di-Sciara G (2018b) Guide to the Manta and Devil Rays of the World. Princeton University Press. 
Stevens GMW, Froman N (2018) Chapter 10: The Maldives Archipelago. In: C Sheppard (ed) World seas: an environmental evaluation, volume 2: the Indian ocean to the Pacific. Elsevier, pp. 211-236

Stewart JD, Beale CS, Fernando D, Sianipar AB, Burton RS, Semmens BX, Aburto-Oropeza O (2016) Spatial ecology and conservation of Manta birostris in the Indo-Pacific. Biol Conserv 200:178-183

Stewart J, Jaine FRA, Armstrong, A, Armstrong A, Bennett M, Burgess K, Couturier L, Croll D, Cronin M, Deakos M, Dudgeon C, Fernando D, Froman N, Germanov E, Hall M, Hinojosa-alvarez S, Hosegood J, Kashiwagi T, Laglbauer B, Lezama-ochoa N, Marshall A, Mcgregor F, Notarbartolo-di-sciara G, Palacios M, Peel L, Richardson A, Rubin R, Townsend K, Venables S, Stevens G (2018) Research priorities to support effective manta and devil ray conservation. Front Mar Sci 5:314

Venables SF, McGregor LB, Brain L, van Keulen M (2016) Manta ray tourism management, precautionary strategies for a growing industry: a case study from the Ningaloo Marine Park, Western Australia. Pac Conserv Biol 22(4):295-300

Ward-Paige CA, Davis B, Worm B (2013). Global population trends and human use patterns of Manta and Mobula rays. PloS one 8(9):e74835

White WT, Corrigan S, Yang L, Henderson AC, Bazinet AL, Swofford DL, Naylor GJP (2017) Phylogeny of the manta and devil rays (Chondrichthyes: Mobulidae), with an updated taxonomic arrangement for the family. Zool J Linnean Soc 82:50-75

Whitehead H (2001) Analysis of animal movement using opportunistic individual identifications: application to sperm whales. Ecol 82(5):1417-1432

Whitehead H (2007) Selection of models of lagged identification rates and lagged association rates using AIC and QAIC. Communications in Statistics-Simulation and Computation ${ }^{\circledR}$ 36(6): $1233-1246$

Whitehead H (2009) SOCPROG programs: analysing animal social structures. Beh Ecol Sociobiol 63(5):765-778 


\section{Figures}

Figure 1: Distribution and sighting abundance of photo-identified reef (Mobula alfredi) and oceanic (M. birostris) manta rays throughout French Polynesia (2001 - 2018).
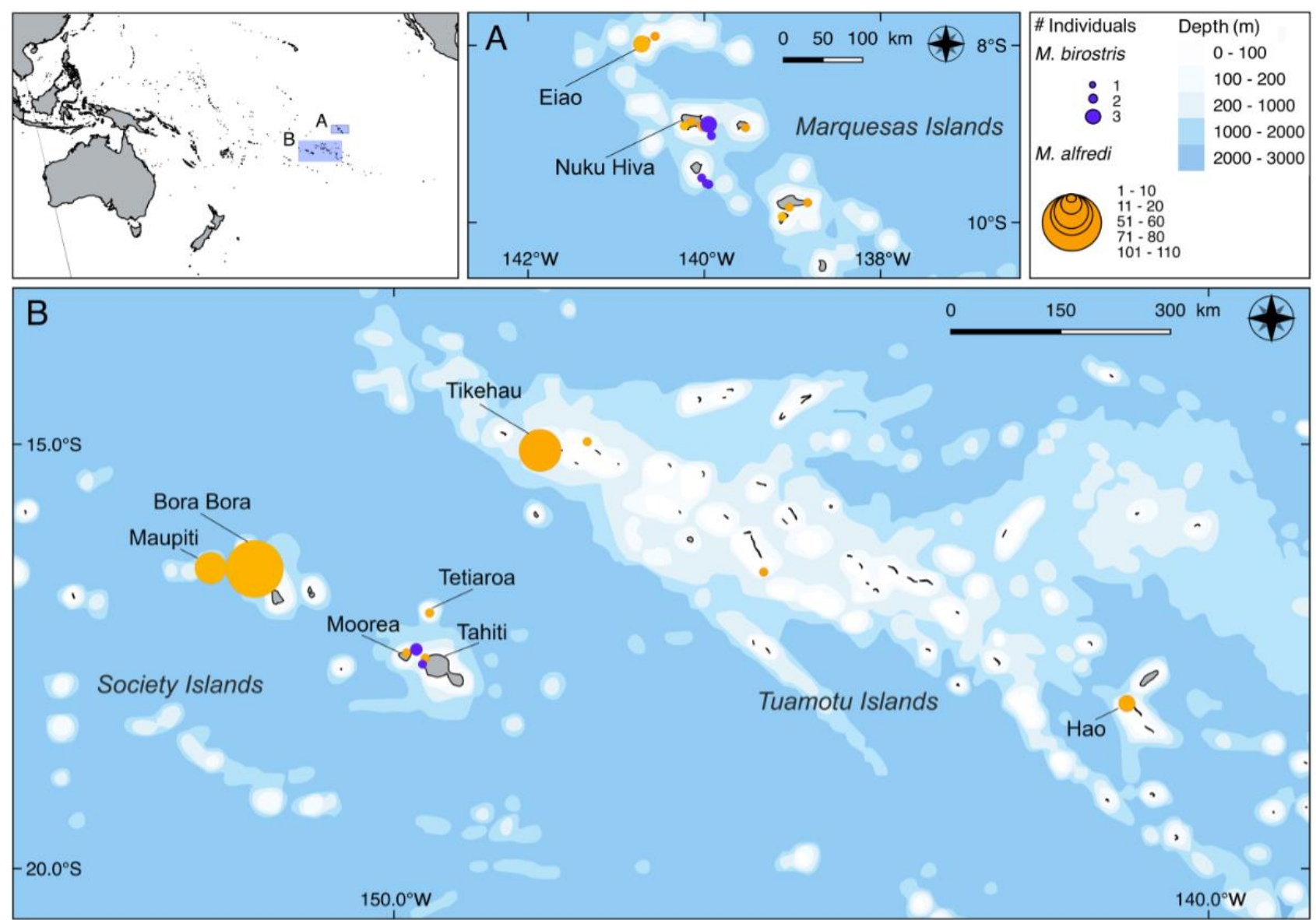
Figure 2: Annual photographic sighting records collected for reef manta rays (Mobula alfredi) at three main aggregation sites (2001 - 2018): two sites in the Society Islands (i.e. Anau in Bora Bora and the Pinnacle in Maupiti), and the site of Tikehau in the Tuamotu Islands. Almost all collected data at Bora Bora, Maupiti and Tikehau were collected by a single observer working in the manta ray diving industry, so the data collection was limited temporally to when the dedicated observer was working for a touristic operator at each site.

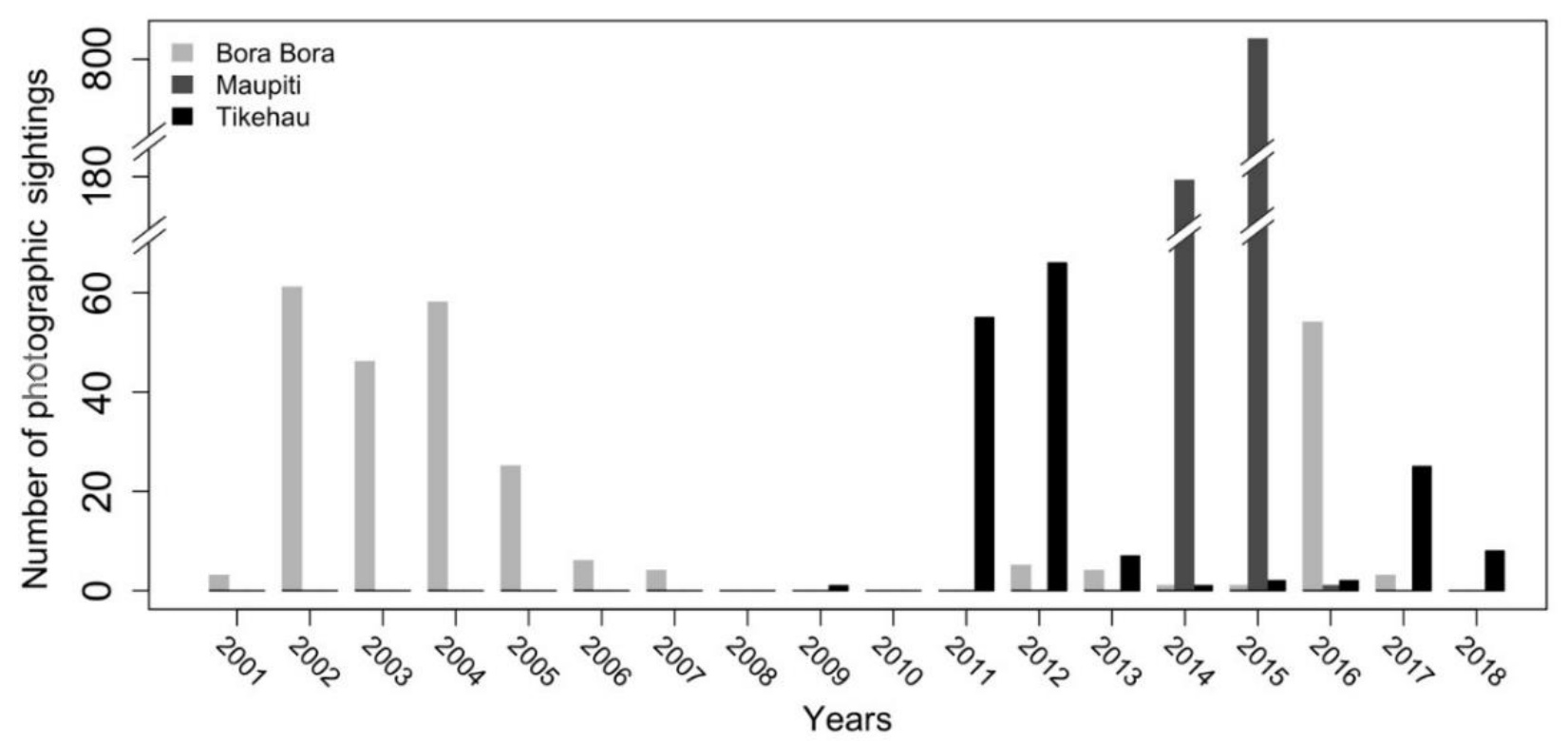


Figure 3: Examples of sub-lethal injuries observed on reef manta rays (Mobula alfredi) in French Polynesia: A1 (08/08/2014, Maupiti) and A2 (24/12/2004, Bora Bora) exhibit injuries caused by boat outboard engine propellers, B1 (16/07/2004, Bora Bora) and B2 (24/11/2004, Bora Bora) are individuals with hooks and fishing lines still attached to their bodies, $\mathbf{C 1}$ and $\mathbf{C 2}$ are from natural predatory attacks (27/11/2011, Nuku Hiva and 03/11/2003, Bora Bora respectively).

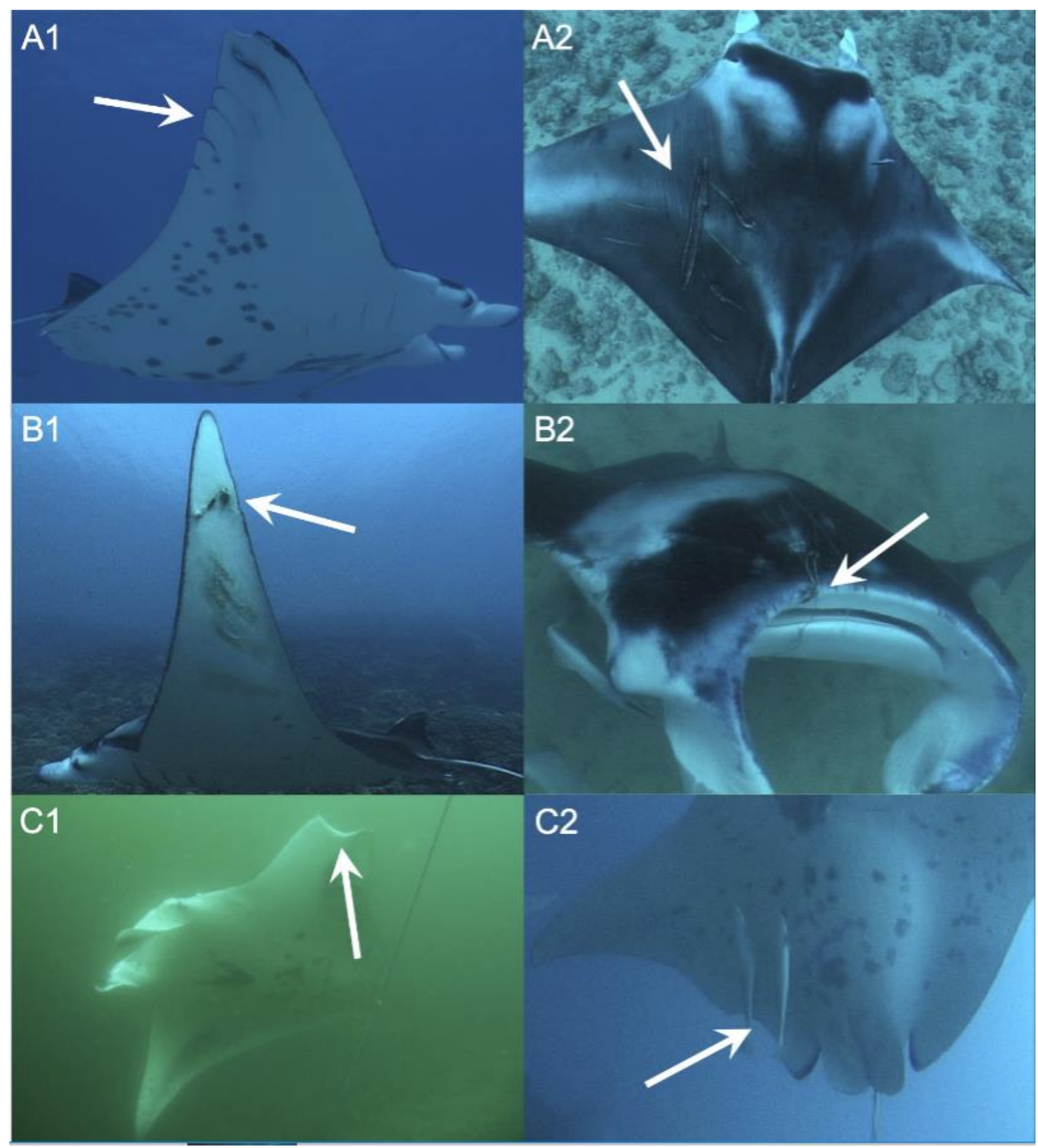


Figure 4: Mean lagged identification rate (LIR) and the curve of the emigration-immigration model best fitting reef manta rays (Mobula alfredi) photographic sighting data against time lag at three main aggregation sites in French Polynesia for periods with the most data available: Bora Bora (20022004), Maupiti (2015) and Tikehau (2011-2013). Vertical lines are standard error given for 1000 runs of the models. Steep decline over short time lags (1 to 150 days after first identification) describes how quickly individuals are leaving the study area after identification. Leveling-off over long time lags suggests manta rays are either returning to the study area or that they never left it.
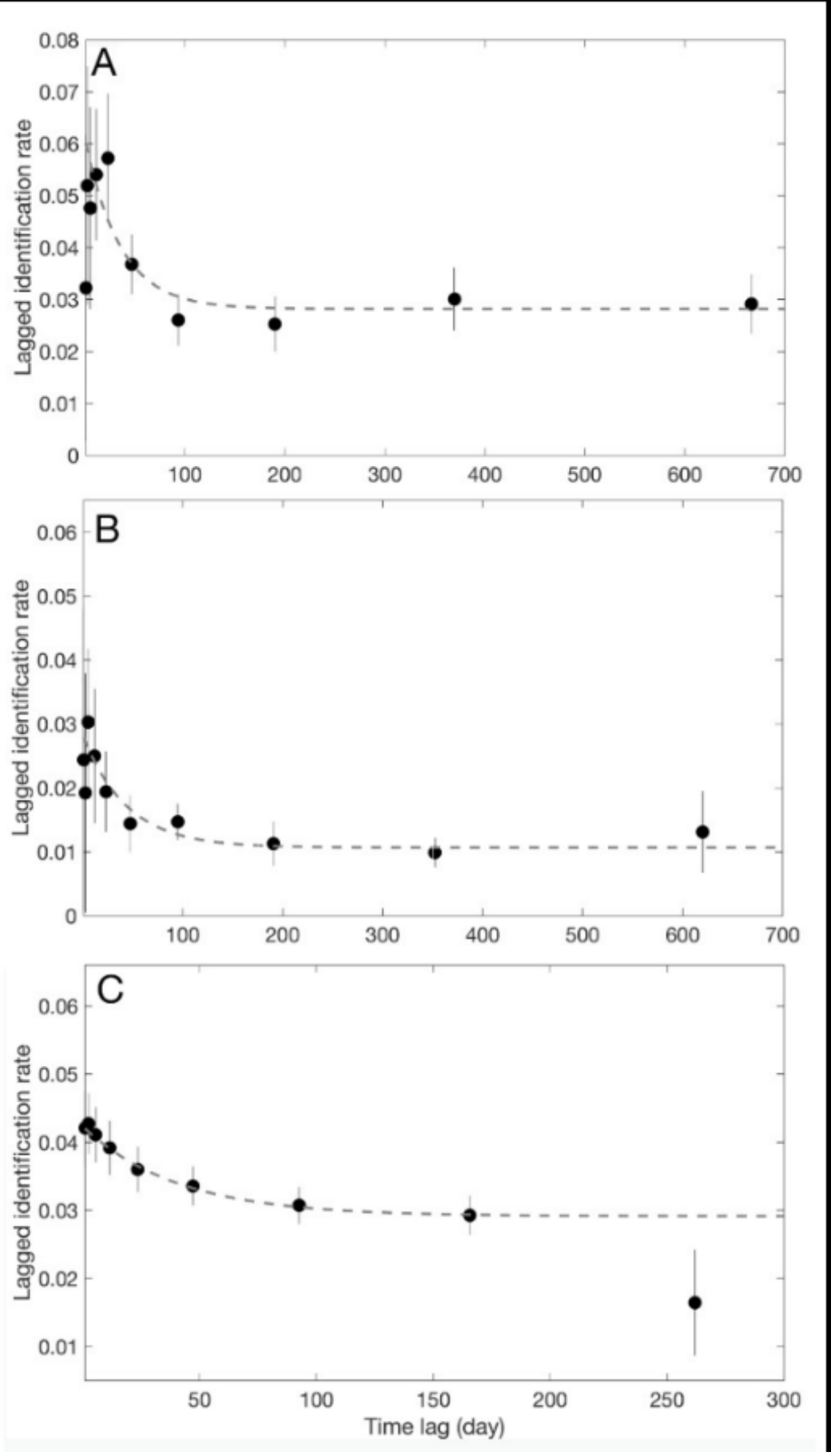
Table 1. Summary of reef manta ray (Mobula alfredi) photographic sightings collected in French Polynesia (2001 - 2018). “\% re-sightings” presents the proportion of the identified population that was re-sighted at least once.

\begin{tabular}{|c|c|c|c|c|c|c|c|}
\hline Location & No. of sites & $\begin{array}{c}\text { No. of } \\
\text { individuals }\end{array}$ & $\begin{array}{c}\text { No. of } \\
\text { sightings }\end{array}$ & $\%$ re-sightings & $\begin{array}{c}\text { Sex ratio } \\
(F: M)\end{array}$ & $\begin{array}{c}\text { No. of } \\
\text { females }\end{array}$ & $\begin{array}{l}\text { No. of } \\
\text { males }\end{array}$ \\
\hline \multicolumn{8}{|c|}{ Society islands } \\
\hline Bora Bora & 1 & 107 & 271 & $36 \%$ & 1:1 & 53 & 52 \\
\hline Maupiti & 2 & 51 & 816 & $90 \%$ & $1: 1.4$ & 30 & 21 \\
\hline Moorea & 1 & 1 & 2 & - & - & 1 & - \\
\hline Tahiti & 1 & 2 & 12 & - & - & 2 & - \\
\hline Tetiaroa & 1 & $\overline{1}$ & 1 & - & - & - & - \\
\hline TOTAL & 7 & $152^{a}$ & 1102 & - & - & $80^{a}$ & $69^{a}$ \\
\hline \multicolumn{8}{|c|}{ Tuamotus islands } \\
\hline Tikehau & 2 & 77 & 140 & $51 \%$ & $1: 1$ & 35 & 34 \\
\hline $\mathrm{Hao}$ & 1 & 20 & 24 & $20 \%$ & 1.3:1 & 10 & 8 \\
\hline Rangiroa & 1 & 4 & 4 & - & $3: 1$ & 3 & 1 \\
\hline Fakarava & 1 & 1 & 1 & - & - & - & - \\
\hline TOTAL & 5 & 102 & 169 & - & - & 48 & 43 \\
\hline \multicolumn{8}{|c|}{ Marquesas islands } \\
\hline Eiao & 3 & 29 & 32 & $10 \%$ & $2.5: 1$ & 20 & 8 \\
\hline Nuku Hiva & 4 & 22 & 22 & $0 \%$ & $2: 1$ & 14 & 7 \\
\hline Hiva Oa & 3 & 8 & 8 & $0 \%$ & $1: 1.3$ & 3 & 4 \\
\hline Hatutaa & 1 & 1 & 1 & - & - & 1 & - \\
\hline Tahuata & 2 & 2 & 2 & - & - & 1 & 1 \\
\hline Ua Huka & 1 & 1 & 1 & - & - & - & - \\
\hline TOTAL & 14 & 63 & 66 & - & - & 39 & 21 \\
\hline TOTAL & & 317 & 1,337 & & & $167^{b}$ & $133^{b}$ \\
\hline
\end{tabular}

a: Ten individuals were sighted at multiple locations within the Society Islands, therefore these duplicates were excluded from the total individual, female and male counts.

b: Sex was undetermined for 17 individuals, resulting in a discrepancy in total number counts. 
Table 2. Model descriptions and fits for reef manta rays (Mobula alfredi) photographic sighting data at three main aggregation sites in French Polynesia for periods with the most data available: Bora Bora (2002-2004), Maupiti (2015) and Tikehau (2011-2013). The model best fitting the data was selected using the Akaike Information Criterion (AIC) for Maupiti and Tikehau's sighting data (no sign of over-dispersion of data) and its quasi-variant (QAIC) for Bora Bora's data as there was over-dispersion in the data. Differences of 0-2 between AIC or QAIC of the best-fit model and other models ( $\triangle \mathrm{QAIC}$ or $\triangle \mathrm{AIC}$ ) indicate strong support; 4-7 indicate some support; and differences greater than 10 indicate no support (Whitehead 2009).

\begin{tabular}{|c|c|c|c|c|c|c|c|}
\hline \multirow[t]{2}{*}{ Model } & \multirow[t]{2}{*}{ Model description } & \multicolumn{2}{|c|}{ Bora Bora 2002-2004 } & \multicolumn{2}{|c|}{ Tikehau 2011-2013 } & \multicolumn{2}{|c|}{ Maupiti 2015} \\
\hline & & QAIC & $\triangle \mathrm{QAIC}$ & $\mathrm{AIC}$ & $\Delta \mathrm{AIC}$ & AIC & $\Delta \mathrm{AIC}$ \\
\hline A & Closed $(1 / a 1=N)$ & 2079,6943 & 5,5197 & 1093,0678 & 4,7361 & 56214,4614 & 8,2514 \\
\hline B & Closed $(\mathrm{a} 1=\mathrm{N})$ & 2079,6943 & 5,5197 & 1093,0678 & 4,7361 & 56214,4613 & 8,2513 \\
\hline C & Emigration/mortality $(\mathrm{a} 1=$ emigration rate; $1 / \mathrm{a} 2=\mathrm{N})$ & 2078,6332 & 4,4586 & 1090,139 & 1,8073 & 56211,0833 & 4,8733 \\
\hline D & Emigration/mortality (a1 = N; a2 = mean residence) & 2078,6332 & 4,4586 & 1090,1389 & 1,8072 & 56211,0833 & 4,8733 \\
\hline E & Closed: emigration + re-immigration & 2083,6562 & 9,4816 & 1096,686 & 8,3543 & 56216,3836 & 10,1736 \\
\hline $\mathrm{F}$ & Emigration + re-immigration & 2074,1746 & 0 & 1088,3317 & 0 & 56206,21 & 0 \\
\hline G & Emigration + re-immigration + mortality & 2082,6331 & 8,4585 & 1094,041 & 5,7093 & 56213,9831 & 7,7731 \\
\hline $\mathrm{H}$ & Emigration + re-immigration + mortality & 2076,1359 & 1,9613 & 1090,2267 & 1,895 & 56208,1629 & 1,9529 \\
\hline
\end{tabular}

Table 3. Maximum-likelihood values for parameters of the emigration-reimmigration model best fitting reef manta ray (Mobula alfredi) photographic sighting data for three main aggregation sites in French Polynesia: Bora Bora (2002 to 2004), Maupiti (2015) and Tikehau (20112012). Periods with the most data available were chosen for the analyses, and the model was fitted for each site's data independently. Means, standard errors (s.e.) and $95 \%$ confidence intervals (95\% c.i.) of the estimates for each site are given for 1000 runs of the models.

\begin{tabular}{|c|c|c|c|c|c|c|c|c|c|c|}
\hline \multirow{2}{*}{ Site } & \multirow{2}{*}{ Period } & \multicolumn{3}{|c|}{ Population size at any given time } & \multicolumn{3}{|c|}{ Residence time in } & \multicolumn{3}{|c|}{ Residence time out } \\
\hline & & $N$ & s.e. & 95\% c.i. & No. of days & s.e. & 95\% c.i. & No. of days & s.e. & 95\% c.i. \\
\hline Bora Bora & $2002-2004$ & 16.39 & 6.62 & $10.57-35.04$ & 65.83 & 290.36 & $17.68-604.36$ & 76.54 & $3.19 \mathrm{e}^{11}$ & $0.05-829.49$ \\
\hline Tikehau & 2011-2013 & 35.37 & 13.56 & $9.96-63.77$ & 70.80 & 129.11 & $2.70-451.43$ & 116.62 & $8.15 e^{13}$ & $0.06-1.39 e^{13}$ \\
\hline Maupiti & 2015 & 23.62 & 2.53 & $18.98-28.47$ & 129.89 & 94.31 & $14.59-394.09$ & 58.75 & $6.01 e^{10}$ & $14.59-875.56$ \\
\hline
\end{tabular}

